マリーナの静穏度に必比スロープの影旺

$$
\text { に咸する数值的検言寸 }
$$

Neumerical Investigation of the Effect of Slope on Tranquility of Marina

\author{
森田修二 ${ }^{*}$. 出口一郎 ${ }^{* *}$ \\ Shuji.Morita and Ichiro. Deguchi
}

\begin{abstract}
Number of people enjoying sailing and cruising is increasing. Acoordingly, number of pleasure boats, especialy illegally moored boats, is increasing. To prepare space for mooring of those boats, various marinas or yacht harbors are planned to be constructed. In such planning, full investigation of the harbor tranquility is hardly done and rough waves of ten cause various troubles in exsiting marinas. Here, the effect of slope of the marina on the harbor tranquility is investigated through numerical and physical model experiment and a procedure for determining the best position of the slope is proposed.

Keywords: (Slope, Marina, Harbor tranquility)
\end{abstract}

\title{
1。まえがき
}

近年、ヨット、モーターボートをはじめとする海洋レジャーが急速にかつ広範に普及し始め、特に不法係留の プレジャーボートの数の増加は社会問題になっている。今後さらに増え続けると予想されるプレジャーボートに 対応するために、数多くのマリーナ、ヨットハーバーの建設が予定されている。従来、このようなマリーナの建 設計画においては、その静稳度あるいは係留される予定のプレジャーボートの動摇問題について詳細な検討が行 われることは希であり、通常は既存資料に基づいた経験的な手法によって行われる。その結果、港内の静稳度が 保たれず係船上の問題を抱えているマリーナも少なくない。マリーナの静穞度を確保する最も効果的な方法は、 外郭施設によって来襲波を少しでも多く遮蔽することである。しかし、遮蔽すればするほど出入港に不便をきた す。一方、通常のマリーナはディンギあるいはその他の陸置き艇の上下架のためのスロープが設置される。その 勾配は、通常 $1 / 10$ 程度であり、反射率は他の護岸や岸壁部よりもはるかに小さい。本研究の目的は、このスロー プの消波効果に着目し、マリーナの静稳度を可能な限り高めることのできる最適な位置について、マリーナに侵 入した波浪変形に関する非定常数値解析を行うことによって検討を加えることである。本論文では、マリーナの モデルを想定し、スロープの無い場合とスロープの配置が効果的と思われる場合を含め幾つかの配置について、 非定常の数值解析によって港内の静稳度の評価を行った。また、実験による検証も行った。

2 . 解析モデルと解析手法

図ー 1 に解析を行ったマリーナのモデルを示した。マ リーナの規模は、汀線方向に $120 \mathrm{~m} 、$ 岸沖方向に $60 \mathrm{~m}$ 、港 口幅は $25 \mathrm{~m}$ である。スロープの幅は $15 \mathrm{~m}$ とし、図中に示 すように 5 力所の場合について港内の静稳度に及ぼす影 響を検討した。数值計算の条件は以下の通りである。

周期

水深

波高

波向

スロープの反射率 0 。

その他の反射率 1 .

空間差分間隔 $\Delta \mathrm{x}=50 \mathrm{~cm} 、 \triangle \mathrm{y}=50 \mathrm{~cm}$

時間差分間隔

$\Delta \mathrm{t}=\mathrm{T} / 100$ 秒

$\mathrm{T}=5$ 秒、 3 秒

$3 \mathrm{~m}$

$30 \mathrm{~cm}$

図中の 2 種類

解析領域岸沖方向 $150 \mathrm{~m}$ 、沿岸方向 $200 \mathrm{~m}$ 計算時間は、港内に約 10 波入射するまでとした。港内

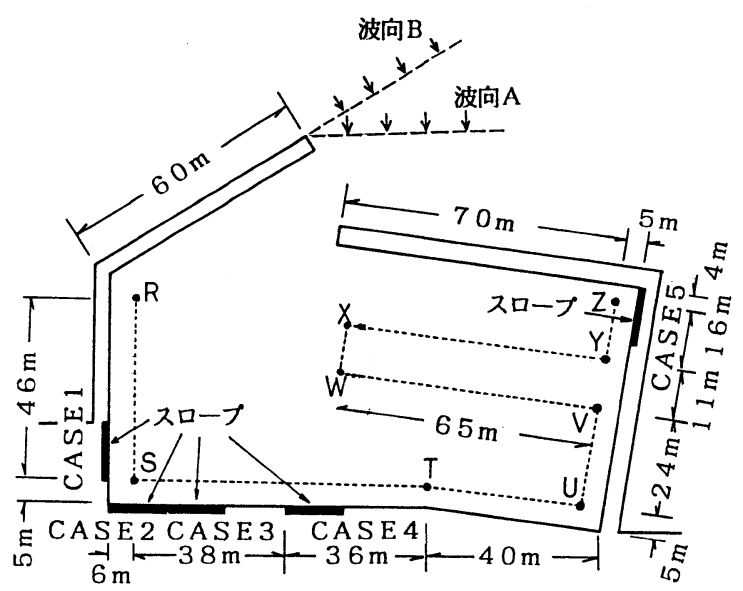

図ー1 マリーナのモデル

* 正会員 料奥村組・電算センター（545大阪市阿倍野区松崎町 2 丁日 2 番 2 号）

** 正会員 大阪大学工学部土木工学科 
の静穏度は、係留地点を想定した図中の点線部分の約120の代表地点について評価を行った。

スロープの反射率ついては、一様勾配斜面に対する反射率としてヒーリーの方法により図ー2(1) のように示 される。本解析の波形勾配は、周期 5 秒の場合で $0.012 、 3$ 秒の場合で 0.024 である。スロープの勾配を10\%とす ると反射率は 5〜10\%になる。通常のマリーナのスロープは、のり先がステップになっており、一様勾配斜面の 場合より反射率が大きくなっている。ここでは、スロープの効果を過大評価することがないように反射率を20\% として検討を行った。スロープの配置は、港内で波高が高くなる位置が効果的と予想される。スロープの無い場 合の解析結果から、港内で比較的に波高の大きい 4 力所（CASE-1〜CASE-4）を設定した。また、参考のために波 高の小さい位置についても 1 カ所 (CASE-5) だけ設定した。

次に解析手法であるが、本解析の条件としては、波の回折と反射が扱えることであり、スロープの反射率を考 慮する必要がある。ここでは、次式に示した規則波に対する非定常の緩勾配方程式に差分法による数値解析を行 った。ここで、Qは線流量、c は波速、らは水面変動量、k は波数、h $\mathrm{h}$ は水深である。

$$
\begin{aligned}
& \dot{\mathrm{Q}}+1 / \mathrm{n} \cdot \mathrm{c}^{2} \nabla(\mathrm{n} \zeta)=0 \\
& \dot{\zeta}+\nabla \cdot \mathrm{Q}=0 \\
& \mathrm{n}=1 / 2 \cdot(1+2 \mathrm{kh} / \mathrm{sinh} 2 \mathrm{kh})
\end{aligned}
$$

本解析では、実際のマリーナの波高を再現すること はできないが、港内の静穞度に対するスロープの効果 を評価することは可能である。また、非定常解析を行 うことで、波高の時間的な推移から波の反射状況を確 認することができる。ここで、非定常解析を行う際に 問題となるのは、境界条件の処理方法である。特に、 港内におけるスロープの反射境界の処理に工夫が必要 である。本解析では、任意反射率境界における波の入

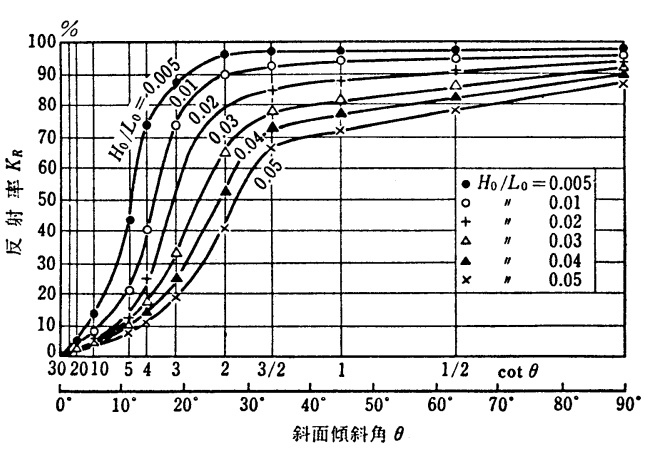

図一 2 一般勾配斜面の反射率 射角を設定するために、港口付近の構造物による波の 回折を数値解析によって求めた。この方法では、港内の反射波に対する任意反射率境界の処理はできないが、ス ロープの幅は相対的には小さなものであり、非定常解析のある限られた計算時間の範囲では問題はないと考えら れる。また、非定常解析における計算時間の制約を考虑して、参考のために定常解析による検討も行った。定常 解析には、規則波に対してグリーン関数を用いたLee ${ }^{(2)}$ の解析手法に任意反射率境界の評価を加えた数值解析法 を適用した。

\section{3. 解析結果と考察}

図一 3 には、 $\mathrm{T}=5$ 秒で波向 $\mathrm{A}$ の代表地点における波高を示したものである。図中の波高は、港内に約 10 波入 射（ $\mathrm{t}=70$ 秒）した時点での波高であり、入射波高で無次元化した值を示している。横軸は $\mathrm{R}$ 点から测線上の延長 距離を示している。図ー 3 の上から順に、CASE-1〜CASE-5の計算結果（太線）にスロープの無い場合の計算結果

（細線）を合わせて示している。

スロープのない場合の波高を見ると、多くの地点で入射波高の50\% 以下になっている。港内の多重反射により 波高のばらつきは見られるが、港内で最初に反射波が生じると考えられる地点（ $\mathrm{s}$ 点付近）では比較的に波高が 大きく、入射波の $80 \%$ を越える地点も存在する。したがって、この領域にスロープを設置すれば効果的になると 予想される。

CASE-1〜CASE-4の結果を見ると、スロープの無い場合の波高がスロープのある場合に比べて小さくなっている 部分もあるが、全体的にはスロープの効果により波高が低下しているのがわかる。特に波高が大きい部分でより 小さくなっている。スロープ付近では当然波高の低下は大きいが、その他の波高の大きい部分（Y点付近）でも 波高の低下が比較的に大きくなっているのがわかる。

CASE-2、CASE-4の結果を見ると、全体的にはCASE-1とほぼ同様の傾向を示していると考えられる。部分的に見 ると、 $\mathrm{s}$ 点の波高の低下はCASE-2の方が大きいこと、Y点付近ではCASE-2、CASE-4は波高の低下が見られないこ と、等があげられる。これらの波高の相違は、反射波の進行方向と関係が媣いと考えられる。CASE-2、CASE-4の スロープの反射波はY点付近よりもW、Xの方向へ進行するため、W、X付近の波高の低下が相対的に大きくな っていると考えられる。これらの結果は、港内の静稳度を評価する上では、入射波の最初の反射あるいは反射波 の評価が重要であることを示唆している。

CASE-3の結果では、代表地点の中での最大波高の低下が最も大きい。CASE-3は、スロープの無い場合に波高が 最大となる境界にスロープを配置したもので、代表地点の最大波高（スロープ無し）もこの境界に近い点となっ ている。また、スロープの無い場合との波形の位置的なずれが、他のケースに比較して大きくなっている。この 


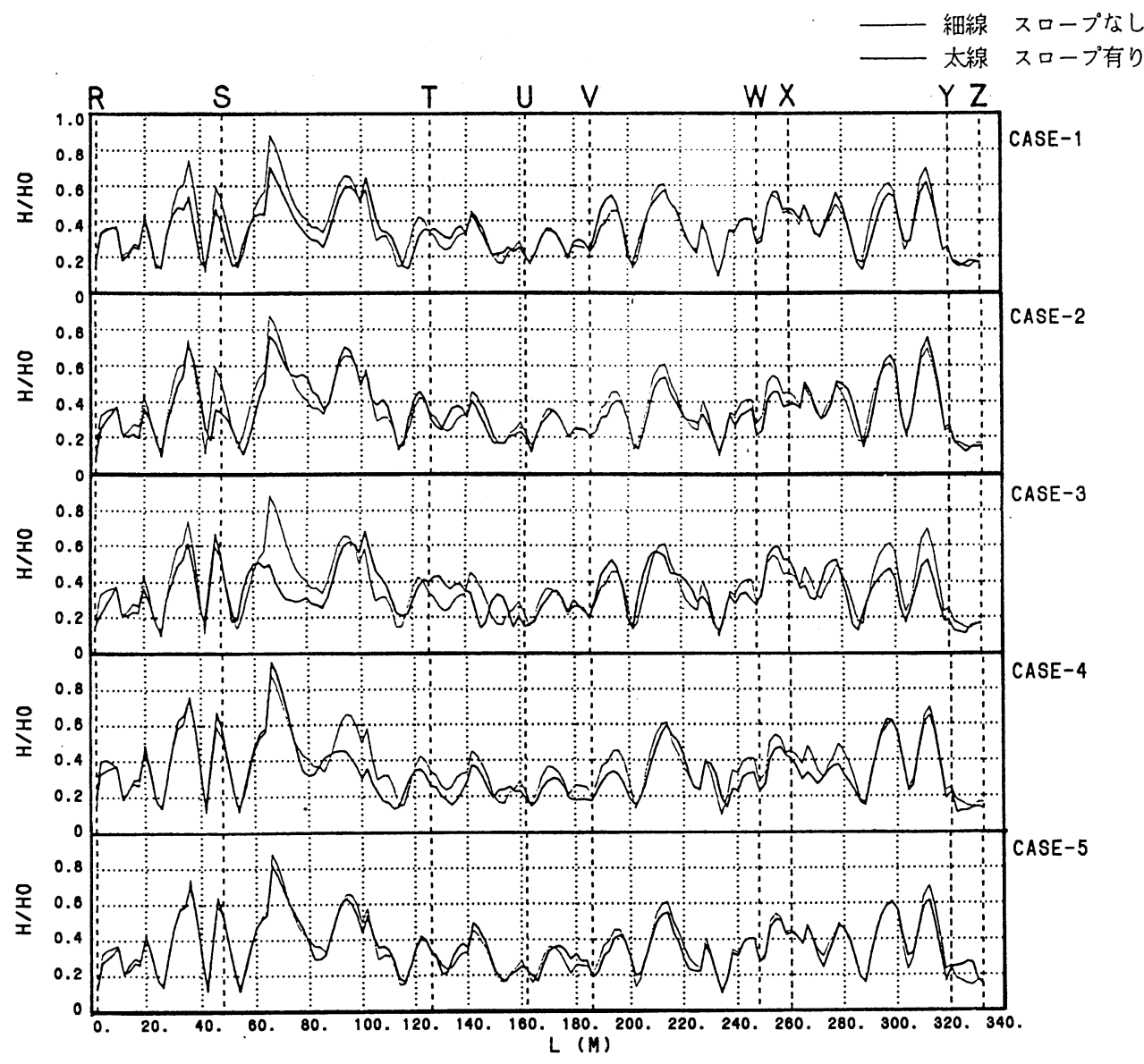

図一 3 代表点の波高（非定常解析）

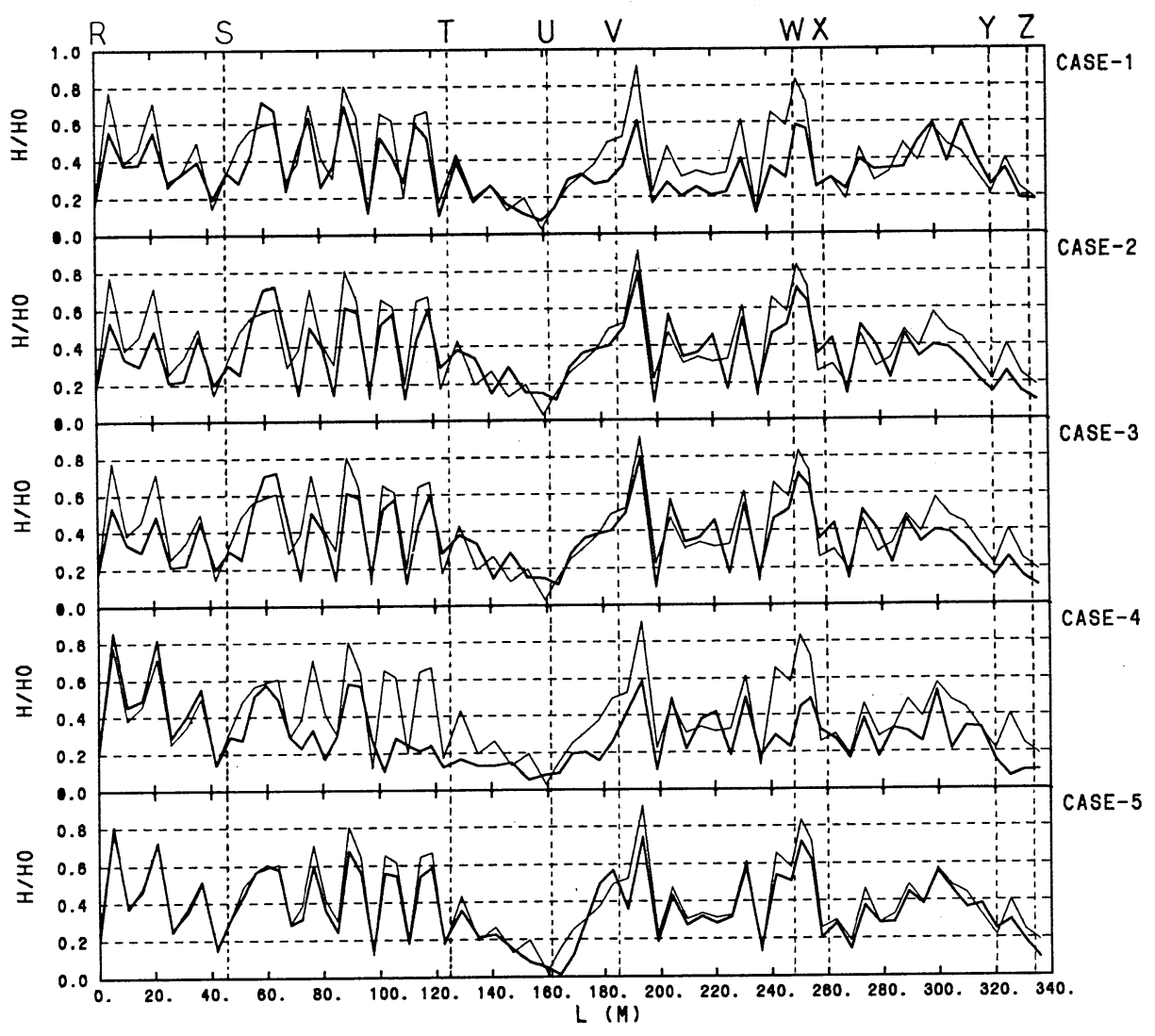

図一 4 代表点の波高（定常解析） 
結果から、CASE-3の場合が最も港内の全域に影響を及ぼ していると考えられる。

CASE-5の結果を見ると、スロープによる波高の低下が かなり小さいことがわかる。他のケースではスロープの 無い場合の波高が大きい境界にスロープを配置したが、 CASE-5は波高の大きくない境界にスロープを配置した。 したがって、スロープの効率的な配置はスロープの無い 場合の結果から推測できることがわかる。

図ー4には、定常解析による結果を示した。図の示し 方は図ー 3 の同様である。ただし、港内の反射率を 0.9 スロープは0.2 として計算を行った。定常解析では非定 常解析に比較して反射波の影響が大きくなるため、反射 率を下げて比較することにした。本文には記述していな いが、港内の反射率が1.の場合の解析も計算を行った。 反射率が 0.9 の場合と比較して波高は大きくなるが、波 形は類似しており、比例的な関係にあると言える。

スロープの無い場合の結果を非定常解析と比較すると 波高が大きくなる地点や $\mathrm{T} \sim \mathrm{V}$ の比較的静稳な領域等、 全体的には良く一致していると考えられる。スロープの 効果についても、非定常解析と同様の傾向が見られる。 したがって、非定常解析の $\mathrm{t}=70$ 秒の結果は、ほぼ定常 解析に近い結果が得られていることがわかる。

図一 5 と図一 6 には、図一 3 と図一 4 の自乗平均波高 と最大波高を示した。非定常解析については計算時間が 30 秒後（港内に約 1 波が入射）から10秒每の結果を示し ている。図ー5では、スロープの有無や配置に関わらず 時間の経過に伴いほぼ同様に波高が増加している。非定 常解析で最も波高の小さいのは、CASE-3あるいはCASE-4 であるが、定常解析では、CASE-4が最も小さく、CASE-3 は比較的に大きい。

図一 6 の最大波高では共通して周期的な振動を示して いるが、CASE-3は比較的変動が小さく絶対値も小さい。 CASE-4は自乗平均波高は小さいが、最大波高は逆に大き くなっている。これは図ー3からわかるように、CASE-4 の場合は $\mathrm{s}$ 点付近の波高の低下がほとんど見られないた めである。定常解析の結果では、CASE-2の最大波高が最 も小さくなっている。図一 3 と図一 4 の比較からわかる ように、波高が最大になる地点が非定常解析と定常解析 では異なるためである。

図ー 7 と図一 8 には、波向 $\mathrm{B}$ の場合の自乗平均波高と 最大波高を示した。図一 7 の自乗平均波高は、波向 $\mathrm{A}$ の 波高の大きさや経時的な変化と大きな違いはない。時間 的に初期の段階では、波高が小さくなっており、港内人 の波の伝播が遅れているのがわかる。波向 $\mathrm{B}$ は波向 $\mathrm{A}$ に 比較して港内に波が侵入しにくいためと考えられる。ス ロープの効果では、波向 B の場合でもCASE-3が最も波高 が小さくなっている。本文では記述していないが、港内 の境界において波高が最大となる地点は波向 $\mathrm{A}$ と同様で あり、CASE-3のスロープが最も効果的であるためと考え られる。

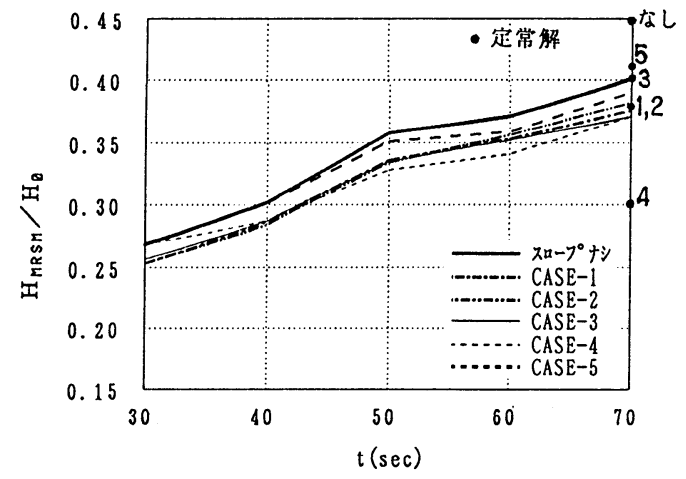

図一 5 自乗平均波高（波向 $\mathrm{A}$ ）

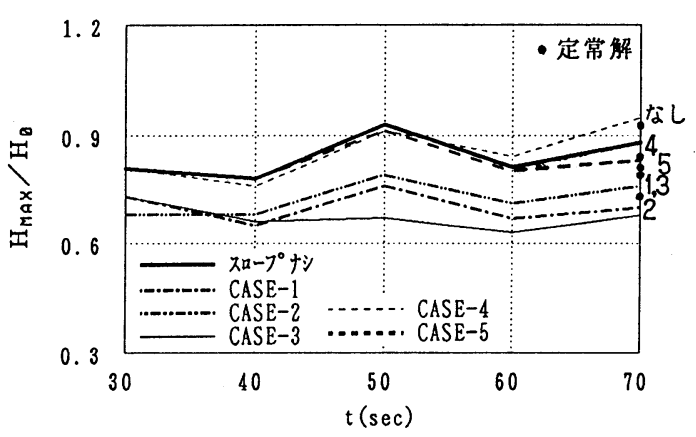

図一 6 最大波高（波向 $\mathrm{A}$ )

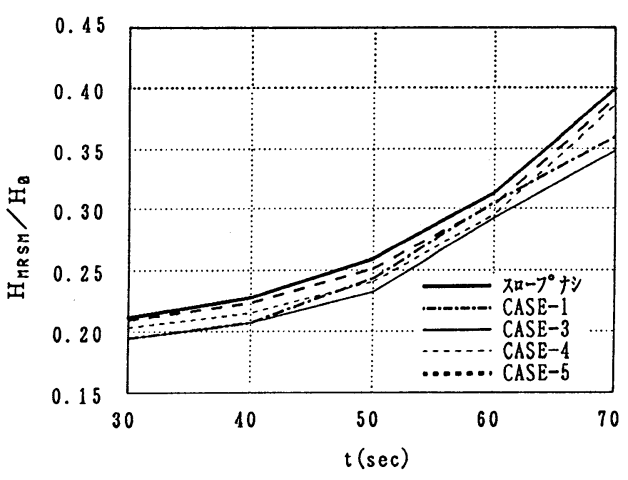

図一 7 自乗平均波高（波向 $\mathrm{B}$ )

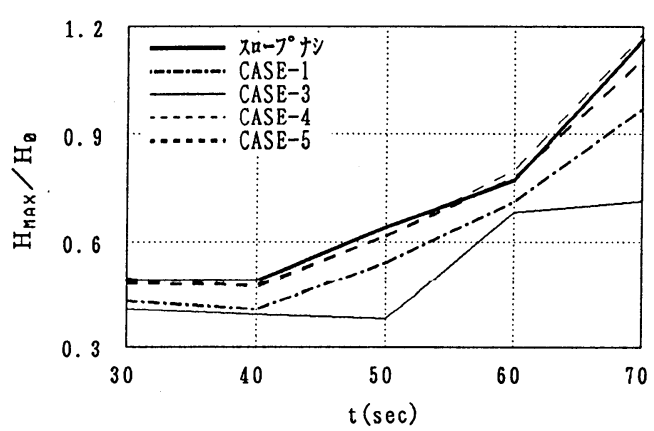

図一 8 最大波高（波向 $\mathrm{B}$ ） 
図一 8 の最大波高は波向 $\mathrm{A}$ と異なり、周期的な振動は 見られず、経過時間とともに波高が大きくなっている。 波向 $\mathrm{B}$ は港内に波が徐々に侵入することから波高の振動 も小さくなると考えられる。時間的に初期の段階では波 高が小さくなっていることやCASE-3の場合の波高が最も 小さくなっているのは自乗平均波高と同様である。

図一 9 と図一 10 には、同じく周期 5 秒、波向 $\mathrm{A}$ の場合 で、スロープの無い場合とCASE-3の70秒後の波高のコン ター図を示した。図一 9 の港口から波が入射して港湾内 で最初に反射して波高が大きくなっている地点にCASE-3 のスロープを設置している。CASE-3のスロープの右側で 波高が大きくなっている地点がCASE-4のスロープの位置 である。港内で最も波高が大きいのは、CASE-3のスロー プの位置とその位置からの反射波の影響と考えられる防 波堤の背面である。

図一10では、波高がかなり低下しているのがわかる。 最も低下しているのはスロープの位置である。また、防 波堤の背面の波高も低下しており、スロープの無い場合 に港内で最も波高の大きかった位置で波高の低下が見ら れるのがわかる。

以上に述べたように、数値解析による検討結果から、 港内静穞度におけるスロープの効果が確認された。スロ ープの配置によってもその効果に違いがあり、スロープ の効果がほとんど見られない場合もある。効果的な位置 は、港内で最も波高が大きくなる位置、あるいは港口か

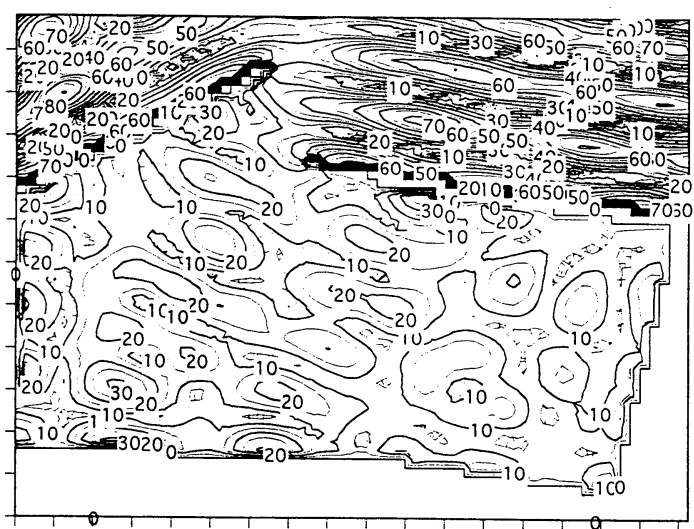

図ー9 波高のコンター（スロープ無し）

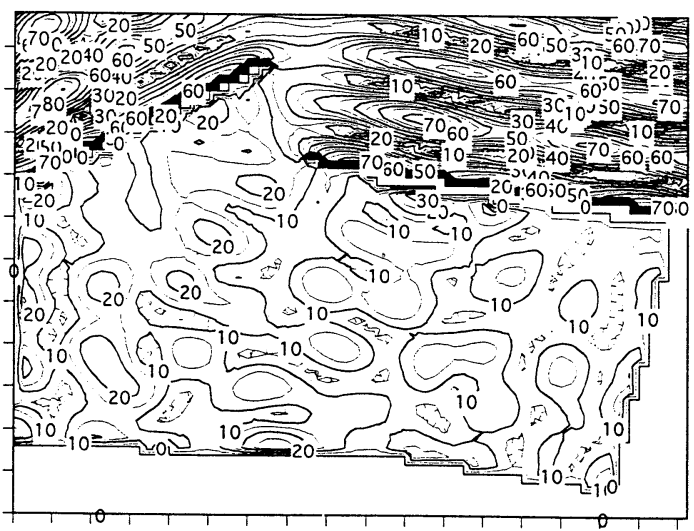

図ー10 波高のコンター (CASE-3) ら入射した波が最初に反射する位置である。本文では、 非定常解析を用いて検討を行ったが、10波程度の港内への波の入射があれば、定性的には定常解析とほぼ同㦈の 結果が得られることがわかった。また、本文には記述できなかったが、周期 $T=3$ 秒の場合には、 $\mathrm{T}=5$ 秒と比 較して、港口からの回折が変化する。港内で波高が最も大きくなる位置がCASE-4の位置になるため、CASE-4の場 合が最も効果的になった。

4. 実験による検証

数值解析による検討結果を検証するために実験を実施 した。図一11に示すように、平面水槽にマリーナの模型 を設置した。実験は周期 $\mathrm{T}=5$ 秒、 3 秒の場合で、計 6 ケースについて実験を実施した。実験の縮尺は数値モデ ルの1/20であり、造波板による波高は砕波のないように 調整した。実験の条件を以下に示す。

$\begin{array}{ll}\text { 波向 } & \text { A (図一 } 1 \text { ) } \\ \text { 周期 } & 1 \cdot 12 \text { 秒、0.6 } 7 \text { 秒 } \\ \text { 波高 } & 3 \mathrm{~cm} \\ \text { 水深 } & 15 \mathrm{~cm} \\ \text { スロープ位置 } & \text { 無し、CASE-3、CASE-4 } \\ \text { スロープ形状 } & \text { 傾斜部の勾配 } 1 / 10 \text { (水深 } 0 \mathrm{~cm} \sim 10 \mathrm{~cm} \text { ) } \\ & \text { 直立部（水深 } 10 \mathrm{~cm} \sim 15 \mathrm{~cm})\end{array}$

図ー11に示した港内の 7 点と港外の 2 点の波高を容量式 波高計により測定を行った。実験時間は 2 分程度とし、 非定常状態の波高に加えて、参考のために定常時の波高 の測定も行った。そのためマリーナの防波堤の前面に、砕石により消波工を施し反射波を極力消すように留意し た。実験の状況を見るかぎり、特に問題となるような反射波はなかった。図一12〜図一15には、周期 5 秒の場合 の波高の経時変化について解析と実験値の比較を示した。実験値には黒丸をつけた。図一 3 と同様に 2 周期毎の 
波高を示している。実験值は、港外の波高を入射波の波 高として、港外の波高に対する比を取っている。図一12 〜図ー14には、测点(2、(4)、(6)の值を示した。

スロープなしの結果では、(2)と(6)は時間とともに波高 が同様に増大しているが、(4)の実験値は途中でピークを とる形になっている。このような大きな変動が見られる のは測点の中で(4)の実験值だけである。

CASE-3の結果では、(4)と(6にはスロープによる波高の 低下はなく、逆に僅かながら増大している。(2)には波高 の低下が見られる。これらの傾向は解析と実験で一致し ている。ただし、(2)実験值は初期の波高低下が大きい ことや、(4)の実験值には初期にのみ波高の低下が見られ る点で相違がある。

CASE-4の結果では、解析は(4)と(6)に波高の低下が見ら れるが、(2)には見られない。実験ではす心゙ての測点で波 高の低下が見られ、低下量も実験值の方が大きくなって いる。

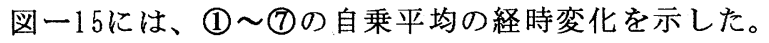
また、参考のために、定常解との比較も示した。解析で は、スロープによる波高の低下は見られるものの低下量 は僅かである。一方、実験では、CASE-3の定常値を除き スロープによる低下が明確になっている。定性的には、

解析、実験ともにCASE-4が最も波高の低下が大きい点で 一致している。項目 3 の図一 5 では、CASE-3が最も波高 の低下が大きくなっているが、図一 3 の中で、実験で選 んだ測点ではCASE-4が最も波高の低下が大きくなってい るためである。

以上の結果を見ると、定量的には解析と実験で相違点 も見られるが、定性的には時間変化やスロープの効果に おいて良く一致している。

5。あとがき

本研究では、マリーナにおけるスロープの波高の低減 効果について数值的検討を加え、実験による検証もおこ なった。検討の結果、スロープの効果はスロープ近辺だ けでなく、港内全体に影響することがわかった。スロー プの効率的な配置は、スロープの無い場合の解析結果に おいて、港内で最も波高の大きい位置あるいは港内に入 射して最初に反射する位置であることがわかった。

解析手法には、緩勾配方程式による非定常解析を用い たが、本研究のマリーナのモデルでは、港内に10波程度 の波が入射するまで計算を行えば妥当な検討ができるこ とがわかった。このことは、定常解析との比較や実験に よる検証から確認できた。今回は実験による検証にとど まったが、今後は現地調査による検証を実施する予定で ある。

参考文献

1)岩坦雄一、椹木 享：「海岸工学」、共立出版、(1985.11)

2)LEE, J.J. : "Wave-induced oscillations in harbours of arbitrary geometry" , J.Fluid.Mech.vol.45, part2, (1971), pp. 375 394

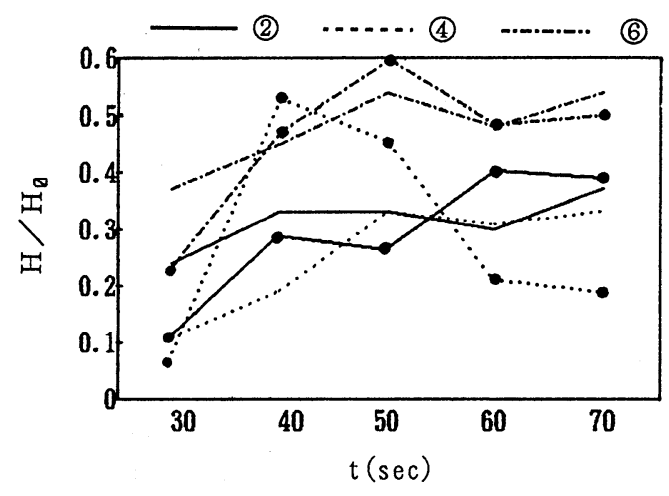

図ー12 測点の波高(スロープなし)

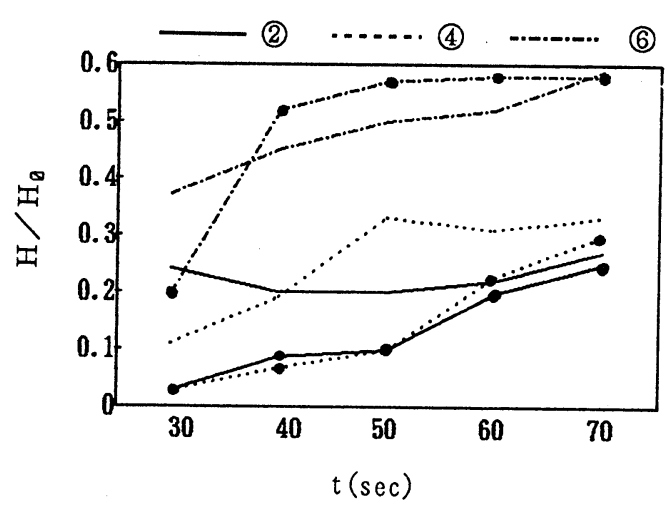

図一 13 測点の波高 (CASE-3)

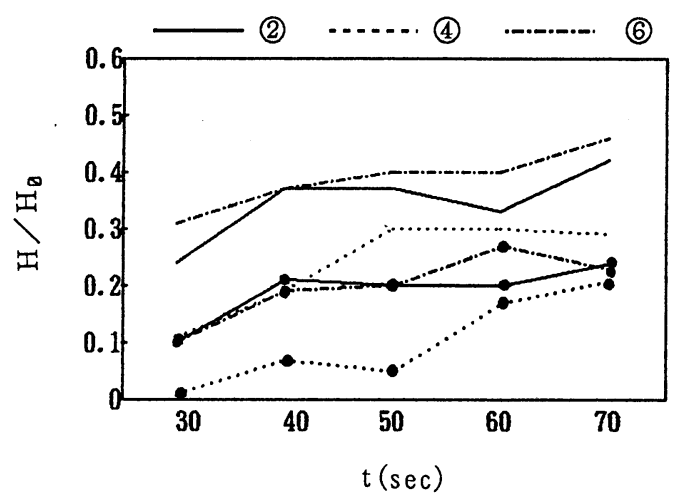

図一14 測点の波高 (CASE-4)

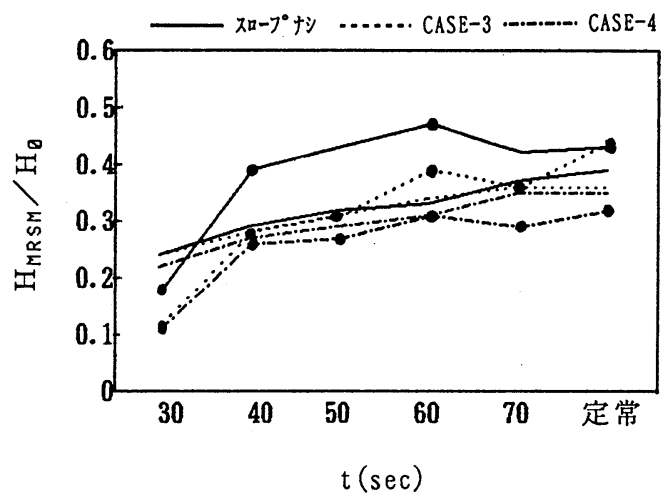

図一 15 測点の自乗平均波高 